\title{
Cotton Zoning Based on Sowing Periods of Lower Risk in Parana State, Brazil
}

\author{
Marcos Silveira Wrege ${ }^{1}$, Paulo Henrique Caramori ${ }^{2 *}$, Sergio Luiz Gonçalves ${ }^{1}$, Wilson Paes \\ de Almeida ${ }^{2}$, Celso Jamil Marur ${ }^{2}$, José Ricoy Pires ${ }^{2}$ and Ruy Seiji Yamaoka \\ ${ }^{1}$ FINATEC - Brasília - DF; ${ }^{2}$ IAPAR, Cx. Postal 481, 86001-970, Londrina - PR, Brazil
}

\begin{abstract}
Cotton is cultivated in the North and West of Parana State, southern Brazil, under conditions of climatic risk variable in space and time. Risks of temperature below $15^{\circ} \mathrm{C}$ at the establishment period, daily average temperature below $20^{\circ} \mathrm{C}$ at the stage of cotton boll opening, and soil water deficit for both plant establishment and flowering periods, were estimated to identify homogeneous zones with sowing periods of lower climatic risk. The time interval with adequate temperature, associated with minimum risks of the other factors and yield data from field experiments allowed the identification of seven distinct zones, with best sowing periods ranging from September 20 to November 20. Official credit to the farmers is conditioned by the Central Bank of Brazil upon following these recommendation of best sowing periods for each municipality.
\end{abstract}

Key-words: Cotton; climatic risk; planting dates; zoning; low temperature.

\section{INTRODUCTION}

The State of Parana (22 to $27^{\circ} \mathrm{S}$ of latitude) comprises the southernmost limit for cotton cultivation in Brazil. The suitable areas in this State have a very high potential for cotton cultivation, due to good soils (EMBRAPA, 1981) and favorable climatic conditions (INSTITUTO AGRONÔMICO DO PARANÁ, 1994).

Several microclimates with distinct thermal and pluviometric regimes are found across the State of Parana, in association with changes in latitude and altitude (Grodzki et al., 1996, Bernardes, 1998). The region is located in a climatic transition zone, from Cfa in the North towards $\mathrm{Cfb}$ in the South, according to Koeppen's classification (INSTITUTO AGRONÔMICO DO PARANÁ, 1994). As cotton is a tropical plant, low temperatures during its establishment and fruit maturation can cause severe damages. According to Lagiere (1969), temperatures lower than $15^{\circ} \mathrm{C}$ during establishment is limiting for plant emergence. For a perfect cotton boll opening, air temperature must be above $20^{\circ} \mathrm{C}$ (Lagiere, 1969; Marur, 1993). The cotton plant can be considered as relatively tolerant to water deficiency. The exception is when dry periods occur during both plant establishment and the first month of flowering (Gridd-Papp, 1965; Marur, 1991), when cotton production can be severely depleted.

In this paper the risk of critical temperatures and water deficit at plant establishment and flowering were estimated to select, in conjunction with experimental data, the most appropriated sowing periods of cotton in Parana State.

\section{MATERIAL AND METHODS}

Based on a series of experimental data on planting dates and variety trials, carried out during several years and localities by IAPAR 
experts, a range of sowing periods was first selected by choosing those with highest average potential yield. The productivity from each municipality in the last 10 years and the cultivated areas in this period were also used as parameters to characterize the most suitable areas and the extreme limits of cultivation.

The cycle of the crop was estimated using growing degree-days (GDD), based on phenological observations made on field experiments. Duration of the phases emergency - flowering and emergency - maturation was estimated for several locations and sowing dates, in order to assess the risk in different crop stages. The following equation was used to estimate degree-days:

\section{GDD = Tmáx + Tmin $-\mathbf{T b}$} 2

\section{If $\operatorname{Tmax}>37.0^{\circ} \mathrm{C}, \operatorname{Tmax}=37.0$}

where:

Tmáx: is the maximum daily temperature; Tmin is the minimum daily temperature; $\mathbf{T b}$ is the lower base temperature $=12.7{ }^{\circ} \mathrm{C}$.

It was assumed that the cotton cultivar IAC 20 (the most cultivated in the State) needs to accumulate the following amounts of growing degree-days in each subperiod to complete its cycle: emergency-beginning of flowering - 600 GDD; beginning of flowering - maximum of flowering - 300GDD; emergency - physiologic maturity - 1650 GDD (Marur, 1993).

Based on the characterization of representative soil profiles that occur in Parana (HAMAKAWA, 1998), the soils were classified in three main groups for the purpose of water retention:

Group 1 - Soils of sandy texture, with $7 \%$ of available water in the root zone;

Group 2 - Soils of medium texture, with $10 \%$ of available water in the root zone;

Group 3 - Soils of clay texture, with $12 \%$ of available water in the root zone.

These information were used to calculate water balance for different sowing periods and localities, as described below. Probabilities of extreme climatic events, defined as climatic risks, were used to assess the potential areas for cotton. These analysis were based on historical series of meteorological data from 32 weather stations of the IAPAR network were analyzed. The duration of the series ranged from 15 to 42 years. The following parameters were considered:

\section{Risk of low temperatures during plant emergence}

Mean daily temperatures below $15^{\circ} \mathrm{C}$ are associated with poor germination and emergence (Lagiere, 1969), thus becoming a restrictive factor in the areas and periods where they occur. In these analyses the periods favorable for sowing were assumed to be those with less than $10 \%$ of probability of temperatures below $15^{\circ} \mathrm{C}$. These probabilities were calculated for moving periods of 10 days (1-10, 2-11, 3-12, etc), from September to December. Multiple linear regressions between the probabilities for each 10-day period and latitude, longitude and altitude were established and used to map the risk of low temperatures in the beginning of the cycle.

\section{Risk of temperatures below $20^{\circ} \mathrm{C}$ at the end of the cycle}

Mean daily temperatures below $20^{\circ} \mathrm{C}$ can stop cotton boll opening (Lagiere, 1969). If a given region does not have enough energy to keep temperature above this threshold, it is not suitable for growing cotton. In order to account for this risk factor, first the cycle was estimated through growing degree-days based on each meteorological station and correlated with latitude, longitude and altitude, in the same manner as described in item 1 , to determine dates of cotton boll opening for each sowing date evaluated. Then maps of probabilities of 
temperature below $20^{\circ} \mathrm{C}$ were overlay with maps of dates of cotton boll opening, to help spatially identifying the appropriated sowing periods. Risk levels lower than $10 \%$ were considered acceptable.

\section{Soil water deficit}

A general model of soil water balance was adapted for cotton to estimate water needs (Oliveira \& Villa Nova, 1996; Wrege et al., 1997, 1998). In this model, the values of crop coefficient $(\mathrm{Kc})$ were defined for each crop stage, assuming fixed values when there is not much vegetative grow, and evolving or decreasing as a function of the relative duration of the cycle (D), as follows:

Phase I - (up to 5,6\% of the cycle): $\mathrm{Kc}=0,35$

Phase II $-(5,7 \%$ to $44 \%$ of the cycle):

$\mathrm{Kc}=0,1229+2,7425 \mathrm{D}$

Phase III - (45\% to $60 \%$ of the cycle):

$\mathrm{Kc}=1,10$

Phase IV - (61\% to $100 \%$ of the cycle):

$\mathrm{Kc}=3,191-2,8907 \mathrm{D}$

Phase V - (100\% of the cycle $)-\mathrm{Kc}=0,30$

Water deficiency in the root zone occurs in the model when water storage falls below a critical value, defined as:

$$
\text { ARMcri }=(1-p) \text {. CAD }
$$

Where: ARMcri is the water storage in the critical limit (mm); CAD, is the water holding capacity in the soil at field capacity ( $\mathrm{mm}$ ); and $\mathrm{p}$ is the fraction of water extracted at the critical level, given by:

$\mathbf{P}=\mathbf{e}^{(\mathbf{A 1}+\mathbf{A} 2 . \mathbf{E T} \mathbf{m})}$

Where:

$\mathrm{ETm}=\mathrm{ETo} . \mathrm{Kc}$;

ETo is the reference evapotranspiration estimated through the equation of PENMAN (1948), using Piche evaporation to substitute the aerodynamic term, as described in WREGE et al. (1997);

A1 $=-0,175$;
$\mathrm{A} 2=-0,1366$.

The values of CAD were admitted to vary according to the soil type and root development. The root system was assumed to have an initial depth of $20 \mathrm{~cm}$, growing exponentially up to 80 $\mathrm{cm}$ at flowering and remaining at this depth until the end of the cycle.

A total of 6 sowing periods were simulated for each weather station, beginning on days 1,11 and 21 of each month, between September $21^{\text {st }}$ and November 20. The water balance was simulated daily throughout the entire crop cycle. The frequencies of water deficit in the periods of plant establishment (sowing date plus 20 days) and during the first month of flowering were considered to be the most critical (MARUR, 1991; Gridd-Papp, 1965), and therefore the average values during these phases were used to characterize the risks related to this parameter.

The choice of best sowing periods was made based on the combination of acceptable risks of low temperatures in the beginning of the cycle and at the stage of boll opening, with minimum risk possible of water deficit. The regions with similar risk were merged and mapped according to the best sowing periods.

\section{RESULTS AND DISCUSSION}

\section{Risk of temperatures below $15^{\circ} \mathrm{C}$ in the beginning of the cycle}

The shaded areas in Figure 1 represent risks lower than $10 \%$, in three different sowing periods. It can be observed that as the sowing periods progress in time the risk decreases, due to the proximity of the warmer season. It can be observed that in September there is a great portion of Parana with high risk of low temperatures during plant establishment. In the beginning of October a significant area has possibility, and by the second decade of October (data not shown) more than $80 \%$ of the area 
would be available. In general, it was verified that for a given sowing date, the risk of low temperatures increases proportionally to altitude and latitude.

\section{Risk of temperatures below $20^{\circ} \mathrm{C}$ at the end of the cycle}

Figure 2 shows the areas with risk lower than $10 \%$ of daily mean temperatures below $20^{\circ} \mathrm{C}$ during cotton boll opening, for three different planting dates. On April 10 all traditional areas where cotton is grown have low risk, meaning that if the cotton bolls are open by this time, there is no restriction related to low temperatures. This corresponds to sowing no later than October 20 on the colder areas where the risk of temperatures below $15^{\circ} \mathrm{C}$ has dropped below $10 \%$.

Based on the analyses, it was concluded that the South of Parana does not have conditions to grow cotton due to the high frequency of low temperatures at the end of the cycle.

\section{Water deficiency during the first month of flowering}

Comparing different regions in Parana (Figure 3 ), one can verify that the risks of water deficit are higher in the Northwest, where prevail the sandy soils, lower rainfall and higher evapotranspiration. The risks are intermediate in the North and very low in the West and Southwest. In the North, the early sowing periods have the lowest risk, which increases up to a maximum of $18 \%$ in November. Considering that temperature is far more limiting for cotton in this region, the advantage of lower risk of water deficiency in very early sowing periods can be suppressed by the deleterious effect of low temperatures in the beginning of the cycle.

\section{Definition of homogeneous zones}

Based mainly on critical temperatures in the beginning and at the end of the cycle, and with the support of data of water deficit, soil types and crop production, seven zones with homogeneous sowing periods of lower risk for cotton were identified, according to Figure 4. Table 1 presents the sowing periods with highest probability of success for each homogeneous zone.

The boarding lines on Figure 4 indicate the transitions between zones, rather than sudden changes. Therefore, near the borders the best sowing period approaches the one of the region on the other side. In all cases, it is advisable to concentrate all the sowing in a short time interval within a region, to avoid pest migration between plantations.

The results presented in this paper represent a significant advance relative to the sowing periods recommended previously. A greater level of detail has been incorporated into the analyses, allowing the identification of distinct risk levels associated with local climate.

The recommendation of best sowing periods based on the present work have been transferred to the Ministry of Agriculture and Central Bank of Brazil, who condition credit approval to the farmers upon adoption of the appropriate sowing period for each municipality. In exchange, the farmer has a more advantageous fee to contract official insurance for his crop and gets complete coverage in case of loss due to climatic disasters. As a consequence, these results are promptly adopted by the farmers, with positive impacts on local agriculture. 

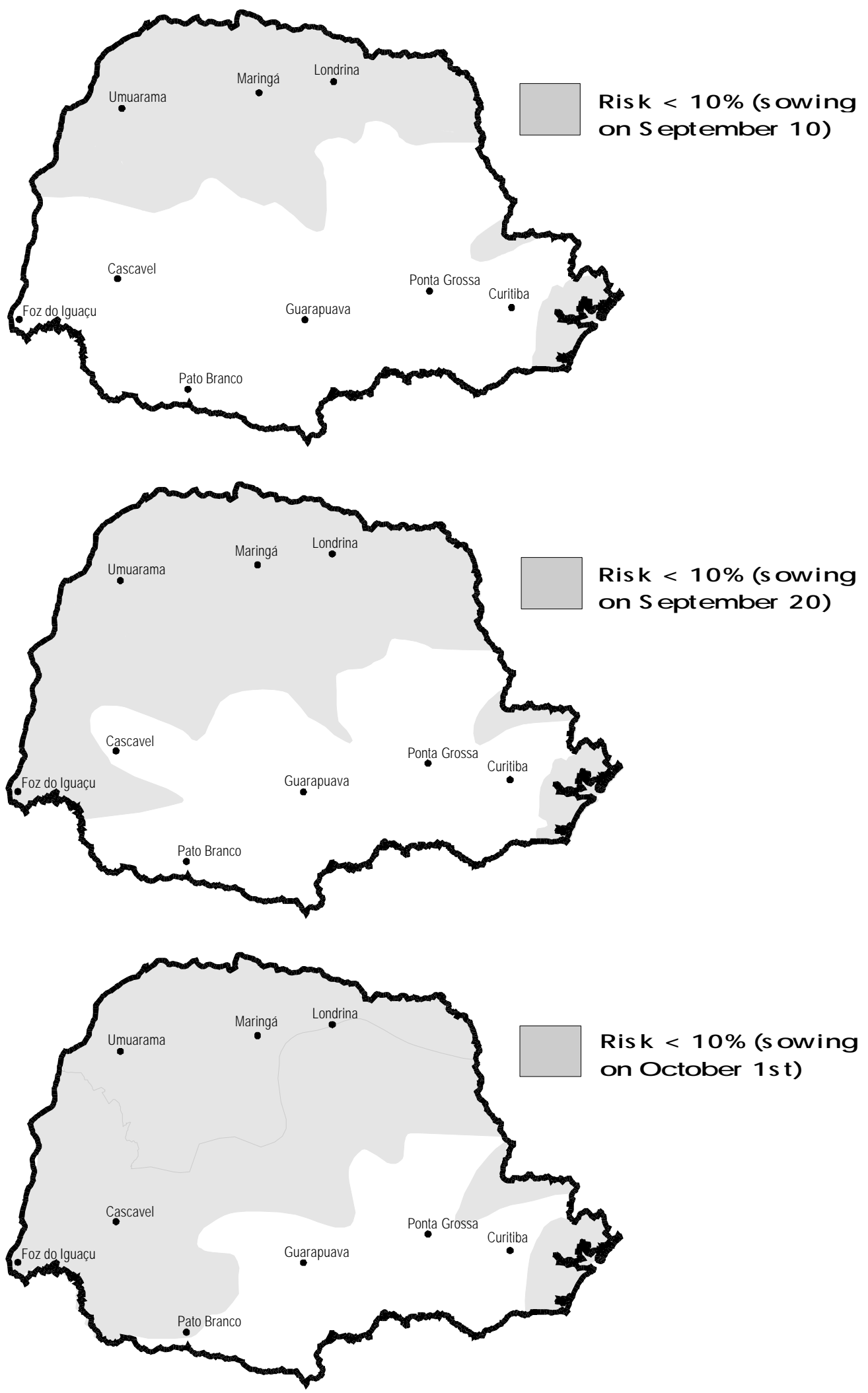

Figure 1 - Risk of mean daily temperatures below 15C during the establishment of cotton in Parana State, Brazil. 



Figure 2 - Risk of mean daily temperatures below $20^{\circ} \mathrm{C}$, during cotton boll opening in Parana State, Brazil. 


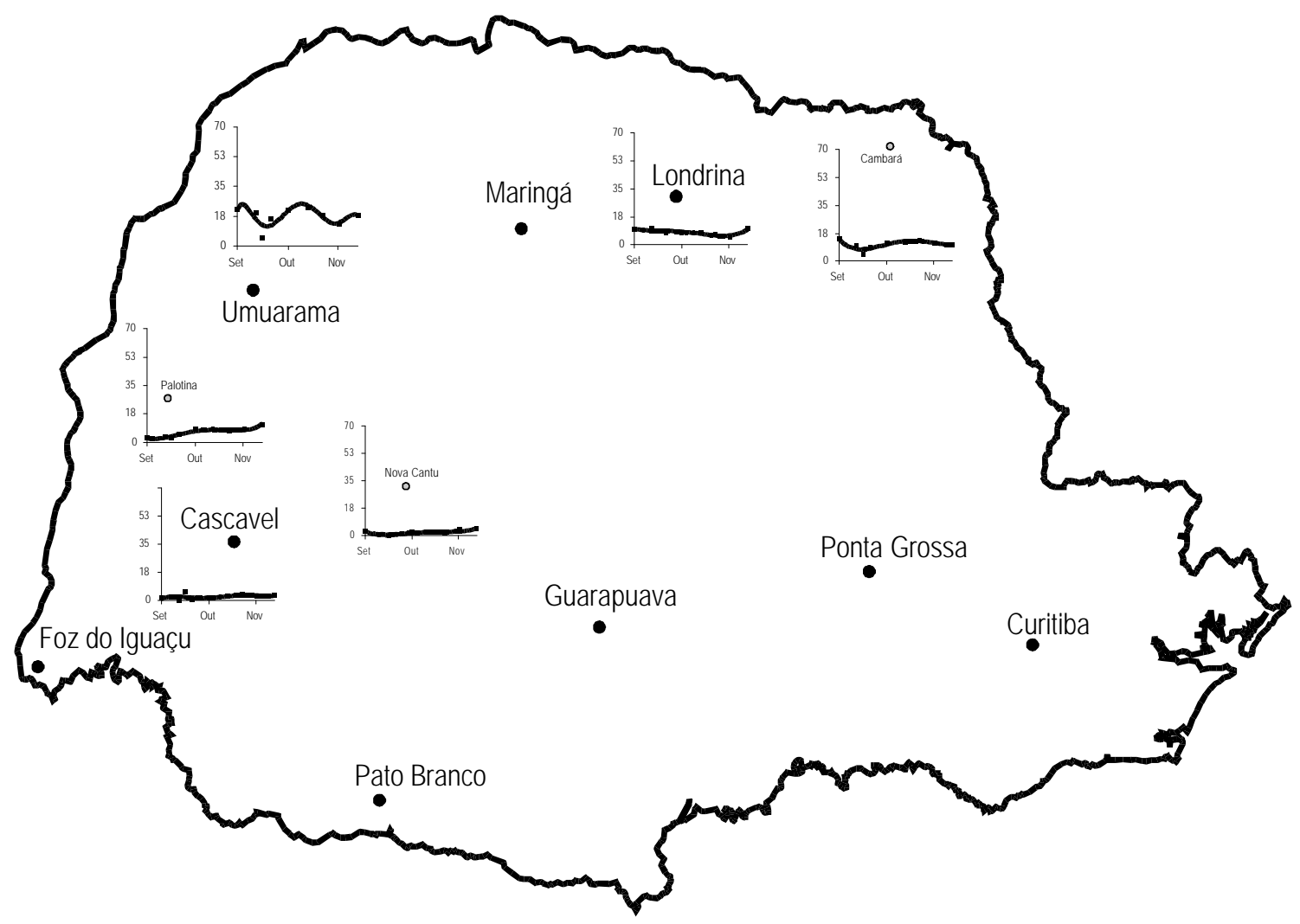

Figure 3 - Percentage of risk of water defic it during the first month of cotton flowering, for different sowing periods in Parana State, Brazil.

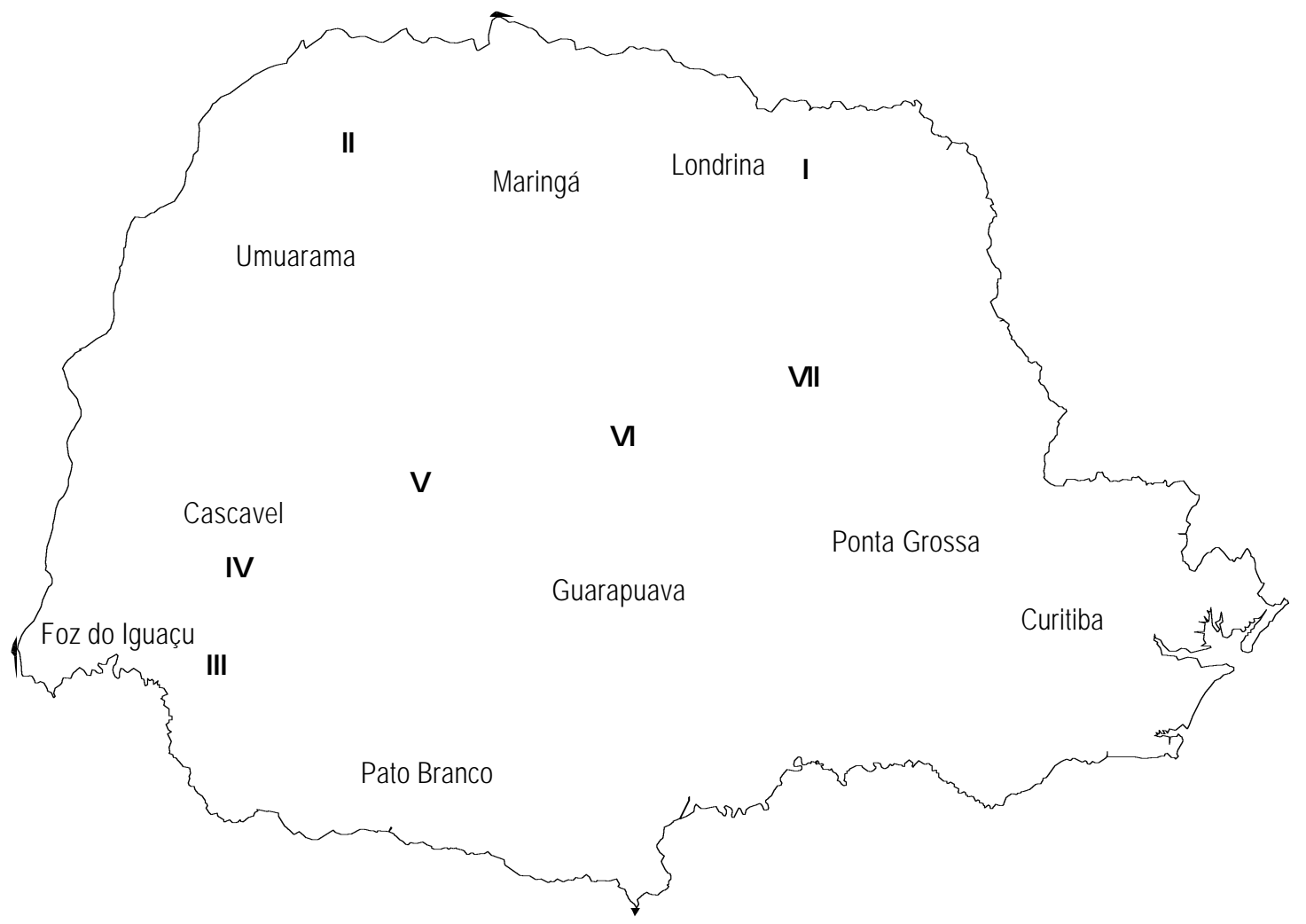

Figure 4 - Homogeneous zones with sowing periods of lower risk for cotton in Parana State, Brazil. The areas in white are not reccomended. 
Table 1. Best sowing periods for cotton in Parana State according to homogeneous zones.

\begin{tabular}{l|l}
\hline Zone & Best sowing period \\
\hline I & September 20 to October 30 \\
II & October $1^{\text {st }}$ to November 10 \\
III & September 20 to October 20 \\
V & October $1^{\text {st }}$ to October 20 \\
VI & October $1^{\text {st }}$ to October 30 \\
VII & October $1^{\text {st }}$ to October 30 \\
\hline
\end{tabular}

${ }^{1}$ The limits of each zone are shown on Figure 4.

\section{ACKNOWLEDGEMENTS}

The authors are thankful to the Brazilian Ministry of Agriculture and to the Fundação de Empreendimentos Científicos e Tecnológicos FINATEC / UNB for financing this research.

\section{RESUMO}

O algodoeiro é cultivado nas regiões norte e oeste do Estado do Paraná, sob condições climáticas de risco variáveis no tempo e espaço. Os riscos de temperatura média do ar abaixo de $15^{\circ} \mathrm{C}$ na fase de estabelecimento da cultura, temperatura média diária abaixo de $20^{\circ} \mathrm{C}$ para completar a abertura das maçãs e déficit de água no solo nas fases de estabelecimento e florescimento, foram estimados para identificar, com o suporte de dados de área plantada e dados de produtividade, as zonas homogêneas com períodos de semeadura de menor risco. Os intervalos de tempo com temperatura adequada, associados com mínimo risco de deficiência hídrica e dados de produtividade, permitiram a identificação de sete zonas distintas, com melhores períodos de semeadura entre 20 de setembro e 20 de novembro. As recomendações de melhores períodos de semeadura para cada município devem ser seguidas pelos agricultores que solicitam crédito bancário oficial para o plantio de algodão.

\section{REFERENCES}

Bernardes, L.R.M. (1998), Determinação de regiões pluviometricamente homogêneas no Estado do Paraná, através de técnicas de análise multivariada. Tese de Doutorado, Escola Politécnica da Universidade de São Paulo, São Paulo, Brazil, 136 p

Empresa Brasileira de Pesquisa Agropecuária / Serviço Nacional de Levantamento de Solos (1981), Levantamento de reconhecimento dos solos do Estado do Paraná. EMBRAPA/ IAPAR/ SUDESUL, Curitiba, Brazil. (Map, scale 1:600.000)

Griddi-Papp, I.L. (1965), Botânica e Genética. In - Cultura e Adubação do Algodoeiro, ed. Instituto Brasileiro de Potassa, São Paulo, pp.117-157

Gonçalves, S.L.; Wrege, M.S.; Caramori, P.H.; et al. (1997), Risco de ocorrência de temperaturas superiores a $30^{\circ} \mathrm{C}$ no florescimento do feijoeiro (Phaseolus vulgaris $\mathrm{L}$.), cultivado na safra das águas no Estado do Paraná. Revista Brasileira de Agrometeorologia, Santa Maria, 5 (1), 99- 
107

Grodzki, L., Caramori, P. H., Bootsma, A., Oliveira, D., Gomes, J. (1996), Riscos de ocorrência de geada no Estado do Paraná. Revista Brasileira de Agrometeorologia, Santa Maria, 4(1), 93-99

Hamakawa, P. (1998), Caracterização físicohídrica dos solos do Paraná. Technical Bulletin IAPAR, Londrina, Brazil. (in press)

Instituto Agronômico do Paraná (1994), Cartas Climáticas do Estado do Paraná. IAPAR, Londrina, Brazil. 49 pp.

Lagiere, R. (1969), Fisiologia e Ecologia. In El Algodon. Barcelona, Spain, pp.29-43. (Colleccion Agriculture Tropical)

Marur, C.J. (1991), Comparação das taxas de fotossíntese líquida, resistência estomática e produtividade de duas cultivares de algodoeiro submetidas ao estresse hídrico. Pesquisa Agropecuaria Brasileira, 26, 153161

Marur, C.J.; Almeida, W.P.; Yamaoka, R.S.; et al. (1993), Recomendações para a Cultura do Algodoeiro no Paraná., Informe da Pesquisa, 107, IAPAR, Londrina, Brazil, pp. 2-8

Oliveira, D. \& Villa Nova, N. A. (1996), Evapotranspiração máxima e lâminas de irrigação necessárias para feijoeiro (Phaseolus vulgaris L.) no Paraná. Revista Brasileira de Agrometeorologia, Santa Maria, Brazil, 4 (1), 29-36

Penman, H.L.(1948), Natural evaporation from open water, bare soil and grass. Proceedings of the Royal Society of London, Series A, London, 193, 120-145

Wrege, M.S.; Gonçalves, S.L.; Caramori, P.H.; Vasconcellos, M.E.C., Oliveira, D., Abucarub Neto, M., Caviglioni, J.H. (1997), Risco de deficiência hídrica na cultura do feijoeiro durante a safra das águas no Estado do Paraná. Revista Brasileira de Agrometeorologia, Santa Maria, Brazil, 5 (1), 51-59

Wrege, M.S.; Gonçalves, S.L.; Caramori, P.H.; Gerage, A.C., Oliveira, D. (1998), Risco de deficiência hídrica na cultura do milho no Estado do Paraná. Pesquisa Agropecuária Brasileira, Brasilia, Brazil (in press).

Received: January 27, 1999; Revised: April 02, 1999; Accepted: May 25, 1999. 